\title{
REVIEW OF DIGITAL TECHNOLOGIES TO IMPROVE PRODUCTIVITY OF NEW ZEALAND CONSTRUCTION INDUSTRY
}

SPECIAL ISSUE: Virtual, Augmented and Mixed: New Realities in Construction

PUBLISHED: December 2019 at https://www.itcon.org/2019/32

EDITORS: McMeel D. \& Gonzalez V. A.

DOI: $10.36680 /$ j.itcon.2019.032

Tabinda Chowdhury, PhD Student,

School of Construction \& Built Environment, Massey University, Albany, Auckland, New Zealand

Email: t.chowdhury@auckland.ac.nz

Johnson Adafin, Lecturer,

School of Building Construction, Unitec Institute of Technology, Mount Albert, Auckland, New Zealand

Email:jadafin@unitec.ac.nz

Suzanne Wilkinson, Professor,

School of Construction \& Built Environment, Massey University, Albany, Auckland, New Zealand

Email: s.wilkinson@massey.ac.nz

\begin{abstract}
The New Zealand construction industry continues to face pressures to improve productivity and lower construction costs. With the need to build more houses and infrastructure, quicker, to high quality and on time, there is a need to upscale the use of advanced technologies. Going digital is a solution that can transform the construction industry by improving productivity measures. The objectives of this paper are to: 1 Identify the availability of transformative technologies and their potential impact on productivity improvement across the construction life cycle and, 2. To investigate the benefits and barriers to technology-uptake in New Zealand construction. This paper is a review of digital technologies which analyzes their impact on productivity across the construction life cycle. As a basis for analysis, the digital technologies are isolated into three key productivity improvement functions: (1) Ubiquitous Digital Access, (2) Whole Building Whole-of-Life (WBWOL) decision making, and (3) Cost Reduction Engineering. This study is a literature-based theoretical exploration, aimed at signifying digitization as a function of productivity performance in the New Zealand construction industry. From a practical perspective, clients and contractors may be convinced to invest in digital technologies, increasing or accelerating uptake and more fully realizing the benefits digital technologies could add to productivity performance, growth and long-term success. This study may provide useful information for researchers regarding the development of case studies by analyzing organizations that implement technological innovations, their successful actions/processes, barriers overcoming actions, and sources of new ideas.
\end{abstract}

KEYWORDS: digital technologies, productivity, construction life cycle, ubiquitous digital access, whole building whole-of-life decision making, cost reduction engineering

REFERENCE: Tabinda Chowdhury, Johnson Adafin, Suzanne Wilkinson (2019). Review of digital technologies to improve productivity of New Zealand construction industry. Journal of Information Technology in Construction (ITcon), Special issue: 'Virtual, Augmented and Mixed: New Realities in Construction', Vol. 24, pg. 569-587,

DOI: $10.36680 /$ j. itcon.2019.032

COPYRIGHT: (0) 2019 The author(s). This is an open access article distributed under the terms of the Creative Commons Attribution 4.0 International (https://creativecommons.org/licenses/by/4.0/), which permits unrestricted use, distribution, and reproduction in any medium, provided the original work is properly cited. 


\section{INTRODUCTION}

Megatrends, like increasing urban populations, often require a rethink of the construction industry to improve productivity whilst providing affordable housing, and expanding capacity of infrastructures (Buehler \& Gerbert, 2017). There is a general consensus in the literature on the sector's fragmented nature (Love \& Irani, 2004), difficult on-site management (Changyoon Kim, Park, Lim, \& Kim, 2013), poor safety concerns (Cheung, Lin, \& Lin, 2018), and project delivery delays (Min \& Bjornsson, 2008) and their impact on construction efficiency. In New Zealand the construction industry is similar in terms of fragmentation, regulatory impediments, and delays (Carson \& Abbott, 2012; Clark-Reynolds \& Pelosi, 2016). Moreover, the need to accommodate the population residing in urban areas, adds requirements for building new infrastructure (BRANZ, 2014). The significance of improving sector productivity, including in housing, was prioritized by the Productivity Commission (2012). Technology improvements have been seen as a way of improving processes to deliver quality, cost-effective buildings needed to meet NZ housing and infrastructure needs (Clark-Reynold and Pelosi (2016)) whilst Macgregor (2017) argues for new methods of construction for improving housing quality. This research posits that digital technologies are a viable solution that can transform the construction sector to improve its overall efficiency. Digital technologies are advanced information and communication technologies that enable capturing, storing, processing, communicating, displaying, integrating and collaborating information (Hamelink, 1997).

For the purpose of this study, digital technologies are referred to as advanced information and communication technologies and tools used in amplifying productivity across construction life cycle. in 1994, Latham's report (1994) aimed to assist the UK construction industry become internationally competitive by recognizing the role of information technology to provide speedy solutions in reducing cost and project duration. Latham (1994) showed a link between productivity, cost, and technology through to economic growth. Economic growth through increasing productivity has also been discussed in Australia, where it is believed that a $10 \%$ efficiency increase in the construction industry productivity would in turn increase the economy's gross domestic product (GDP) by over $2.5 \%$ (ICCPM, 2014). Similarly in New Zealand, $1 \%$ increase in sector productivity would generate an increase in GDP of around $\$ 139 \mathrm{~m}$ annually (PWC, 2016). One way of improving productivity is through the advanced use of digital technologies.

Several reports systematically reviewed digital technology applications for multiple functional areas, for instance construction safety (W. Zhou et al., 2012); Radio Frequency Identification Technology (RFID) in construction (Valero et al., 2015); and construction progress tracking (Omar \& Nehdi, 2016). The current paper extends recent literature reviews on the theoretical applications of digital technologies in order to understand the relationship between digital technologies and productivity. Much literature has suggested various barriers to digital-innovation development, but researchers have not fully understood the productivity gains generated from digital technology investment. (Aouad et al., 2010; Ramilo and Embi, 2014).

In the literature on technological innovation, a key task is to investigate how new technologies can be adopted to reshape the construction industry for the better (Loosemore 2014; Gambatese and Hallowell, 2011; Shibeika and Harty, 2016). Using previous studies, this research aims to identify the availability of digital technologies and investigate their impact on productivity enhancement for the construction sector. How digitization impacts productivity is poorly understood, creating an area for this research. The research specifically examines the applicability of digital technologies in the New Zealand construction industry.

\section{LITERATURE REVIEW}

\subsection{Defining digital technologies}

An early study by Hamelink (1997) addressed the evolution of digital technologies as they occurred in four phases: mechanical phase - Industry 1.0, electrification phase - Industry 2.0; digital computers and telecommunication phase - Industry 3.0; Information and communication technology (ICT) development phase - Industry 4.0. Hamelink (1997) referred to digital technologies as advanced ICT that enable capturing, storing, processing, communicating, displaying, integrating and collaborating information. A number of authors have later classified these technologies according to their specific context of study. Froese (2010) referred to digital technologies as paradigm shift in the use of emerging IT, such as computer aided design (CAD), email, building information modelling (BIM), and web based project management (WBPM) applications. From the account of Ibem \& Laryea 
(2014), digital technologies are stand-alone, web based technologies and tools used for executing construction procurement activities. Whyte \& Lobo (2010) identified role of digital technologies to facilitate social interactions, knowledge sharing, and coordination practices among stakeholders. Ibrahim (2013) addressed digital technologies as innovations that support construction procurement, management, and delivery of building projects. Hence, digitization such as the internet, smart devices, cloud computing, and other data processing technologies could remove constraints upon volume and reliability of data handling and quicken the speed of data transmission geographically (Underwood \& Isikdag, 2011). Digital technologies appear to offer benefits throughout the construction supply chain (Balfour Beatty, 2017) and digital disruption could change the future of New Zealand's construction industry (EBOSS, 2017).

\subsection{Digital innovation in context and barriers}

Rapid growth of demand in exploiting technology is globally identified (Shibeika and Harty, 2016), as challenges with productivity, cost and quality achievement are endemic in the building industry (Xue et al., 2014). Schoenborn (2012) linked these challenges with a slow uptake of new technologies. Globally, the industry has lagged behind most other industries in technology adoption and implementation (Stewart et al. 2004; Construction Industry Institute, 2008; Hooper and Haris 2010; Sepasgozar et al. 2016) and construction is recognized as a rather lowtechnology sector (Noktehdan et al., 2015). Evidence has shown that the New Zealand construction sector appears to be a low-technology performer with an insignificant contribution (5\% of total expenditure) to Research and Development (R\&D) expenditure when compared to all-industry averages (Statistics NZ, 2012). However, New Zealand's Business Growth Agenda 'Building a Digital Nation' released the 'Digital Economy Programme' with an aim to enable New Zealand to become a leading Digital Nation where business, people, and government would use digital technology to drive innovation, improve productivity, and enhance the quality of life for all New Zealanders (Business Growth Agenda, 2017). The significance of digital technology on various sectors of the economy is also a key focus of the Digital Nations 2030, which is an industry inclusive summit supported by the New Zealand Government (ICT.govt.nz, 2017).

Arguably, the global construction community has witnessed increasing efforts in recent years, introducing new technologies to improve productivity, lower costs, increase quality and sustainability (Loosemore, 2014). For example, the UK government fostered a culture of innovation in technology to achieve a technologically advanced construction sector by 2025 (Shebeika and Harty, 2016). However, circumstances emanating from emerging technologies have posed a hindrance to investors, thus diffusion has been a major challenge (Gledson and Phoenix, 2017). As evidenced in Suprun and Stewart (2015), recent research by the Russian Federal State Statistics Service [FSSS] (2014) found that only the high-tech sectors such as information and communication technologies, biotechnology and nanotechnology have improved in terms of innovative technology compared to other sectors (e.g. construction, manufacturing, etc). Following a similar study by Loosemore (2014), based on a comprehensive survey of Australia, the sector has been identified as a low-technology achiever with only $30.8 \%$ of businesses innovating.

Like most countries, the New Zealand building industry continues to face pressures for improving productivity and lowering construction costs (NZ Institute of Economic Research [NZIER], 2014). Change in the construction sector is overdue, thus in 2016, the Building Better Homes, Towns and Cities' National Science Challenge was established to actively address the challenges of low productivity within the sector and improve the quality and supply of housing stock (MBIE, 2016). The incorporation of new technologies that embrace systems, tools and equipment, and new resources used in the process of design/construction to digitize the building industry has become a major focus.

While Brandon and $\mathrm{Lu}$ (2008) suggested that global construction is moving towards a machine-dominated sector; in a follow-up study, Froese (2010) published a wide range of digital innovations that can influence the functions of construction firms and have potential positive impact on productivity and affordability. These include the applications of digital technologies in design and construction to improve visualization (Patacas et al. 2015), ubiquitous access to on-site and off-site information (Ruwanpura et al. 2012), safety control (Zhou et al. 2012), communication (Vlist et al. 2014), and progress monitoring (Zhang \& Arditi, 2013). Other concepts that are currently attaining the most widespread interest include 3D printing, artificial neural network (ANN), artificial reality (AR), autonomous vehicle/robotic system, barcode technology, building information modelling (BIM), case-based reasoning (CBR), cloud computing, electronic commerce (e-commerce) technologies including web- 
based project management, game technology, geographical information system (GIS), global positioning system (GPS), 3D scanner, mobile devices (smart phones, tablets, etc.), virtual and augmented reality, internet of things (IoT), big data and analytics, stereo-lithography, mobile and wearable technologies, GPS guided plant and machinery and nanotechnologies, and smart materials and building components, to name a few (Sepasgozar et al., 2016). This was corroborated by Miettinen and Paavola (2014) that the synergistic application of digital technologies makes information available through interconnected automated systems. For example, integrating AR technology in BIM for on-site information system of construction site activities (Wang et al. 2014). Some of these technologies have produced productivity improvements up to $40 \%$, satisfying a much-needed enhancement in efficiency (Zhou, Whyte, \& Sacks, 2012; Guo, Scheepbouwer, Yiu, \& González, 2017). Diffusing digital technology can lead to significant productivity improvements but these impacts are poorly understood. Similarly, these technologies are transformative (World Economic Forum, 2016), and could motivate locally- based solutions for innovation adoption and implementation.

To gain a deeper insight into the innovative technology, the USA innovativeness provides some insights. In Gambatese and Hallowell's (2010) study, results (see Table 1) revealed an analysis of the expected benefits of innovative technologies on quality, productivity and cost. Participants in the study were asked to identify and rate these benefits. The result further shows the responses in comparison to the motivators for implementing the innovations. Decreased cost, competitive advantage, higher quality and increased productivity were the most highly rated expected benefits of the innovations. The core lesson that can be learnt from Gambatese and Hallowell, (2011) is that innovation benefits can best be achieved through organized effort to invest in new ideas and convert them into practice in a systematic way.

Table 1: Comparison of innovative-technology benefits and motivators

\begin{tabular}{lll}
\hline Factor & $\begin{array}{l}\text { \% of respondents that identified the } \\
\text { factor as a significant or higher } \\
\text { motivator }\end{array}$ & $\begin{array}{l}\text { of respondents that identified } \\
\text { higher benefit a significant or }\end{array}$ \\
\hline Cost & 89 & 66 \\
Productivity & 80 & 71 \\
Quality & 83 & 80 \\
Competitive advantage & 85 & 90 \\
Market share & 59 & 48 \\
Safety & 65 & 63 \\
Marketing & 51 & 48 \\
New market & 52 & 57 \\
\hline
\end{tabular}

Source: Gambatese and Hallowell (2011)

Substantive research has been carried out on introducing digital technologies in construction (Sepasgozar et al., 2016), a significant outcome of which is the identification of numerous barriers (cultural, organizational, institutional, technological, financial, etc.) to technology adoption by some authors (Ramilo and Embi, 2014; Skibniewski, 2014) which include (Cory and Bozell, 2001; Jones and Saad, 2003; O'Sullivan, 2002):

- Inherent problem in the innovation;

- $\quad$ Lack of mutual recognition of the need for innovation;

- Insufficient technical capabilities and skill levels;

- $\quad$ Reluctance to change;

- Inexperienced team members;

- $\quad$ Lack of training;

- Weak commitment and support by top;

- Inadequate resources;

- Lack of integration and collaboration;

- $\quad$ Lack of learning environment;

- $\quad$ Lack of incentives; and

- Difficulty in complying with the existing regulations and established standards. 
Much of this research affirmed that technological advancement of the digital technologies has the potential to improve cost, quality and productivity significantly (Gambatese and Hallowell, 2011; Ramilo and Embi, 2014). However, some studies show that significant technical and organizational barriers exist, that impede the effective adoption of these technologies (Ozorhon et al., 2010; Ramilo and Embi, 2014; Hemstrom et al., 2017). A Malaysian industry-wide survey found risk and liability, high equipment cost, financial disincentives, inadequate $R \& D$ investment, lack of capable people, inadequate technology transfer, inflexible building codes and standards, and lack of governmental support as major challenges to new ideas (Civil Engineering Research Foundation, 1996; Romilo and Embi, 2014). The current study posits that the factors that impede new ideas are complex (Shelton et al., 2016), hindered by the unique culture and characteristics of the construction industry, and its operational environment (see Table 2).

Table 2: Overall results of descriptive statistics of the most significant barrier to digital technology adoption among architectural firms (small, medium and large) in Singapore

\begin{tabular}{llll}
\hline Barriers & N & Mean & Standard Deviation \\
\hline Technological barrier & 45 & 26.3111 & 12.37817 \\
Organizational barrier & 45 & 25.7333 & 16.71336 \\
Financial barrier & 45 & 29.9556 & 11.13748 \\
Process barrier & 45 & 26.1556 & 2.48592 \\
Psychological barrier & 45 & 24.5556 & 14.54078 \\
Governmental barrier & 45 & 5.5333 & 2.88885 \\
\hline
\end{tabular}

Note: $N=$ number of respondents $(N=15$ for each category of the firms [small, medium and large]); Likert scale used =0-5 for each category of the firms; Each mean score is an average derived from the statistics of each category of the firms; The higher the mean score, the more likely that the barrier is the most significant in digital technology adoption. Source: Ramilo and Embi (2014)

A Singaporean industry-wide survey (Ramilo and Embi, 2014) found financial concerns (Mean = 29.9556; see Table 2) as the most significant barrier to digital technology adoption among architectural firms (small, medium and large). In Ozorhon et al.'s (2010) report, economic conditions and availability of financial resources are clearly seen as two top barriers to the adoption/implementation of innovative technology in the UK. Similarly, with architects' perception of the Swedish construction industry, Hemstrom et al. (2017) indicated financial issues as barriers to the innovativeness of the industry. Thus, financial implications play a significant role in digital technology development.

Several international studies on construction digitization obtained data from study areas such as Asia, Australia, Middle East, United Kingdom, and United States (Gambatese and Hallowell, 2011; Ramilo and Embi, 2014; Shibeika and Harty, 2016). A key task is how digital technologies can be upscaled to shape the future of construction

\subsection{Linking digital technologies to construction life cycle activities}

The construction life cycle is embedded in the management of construction projects in order to add value to services, reduce the whole life cost, and improve overall productivity (Lee, Song, Oh, \& Gu, 2013). Since New Zealand is the context region of study, authors refer to the construction life cycle framework established by BIM Acceleration Committee in New Zealand (2014): pre-design, design, construction, operate, renovate. Findings from these reveal that out of 144 papers reviewed, most papers address digital technology application in design and construction phases, whereas no application targeted renovate/refurbishment/retrofit phase. Also, in view of the surveyed literature on digital technologies, Table 3 identified aspects of the construction life cycle activities enabled by digital technologies. 
Table 3: Construction life cycle activities identified from literature

\begin{tabular}{|c|c|}
\hline Author & \\
\hline Yau \& Yang (1998) & $\begin{array}{l}\text { Feasibility study, conceptual planning, preliminary design, detail design, procurement } \\
\text { and contracting, construction, operation and maintenance, dismantle and rebuild }\end{array}$ \\
\hline $\begin{array}{l}\text { Kumaraswamy et al. } \\
\text { (2004) }\end{array}$ & $\begin{array}{l}\text { Construction information management; Collaborative decision making among } \\
\text { stakeholders; Quality management process; Design development; Integrated supply } \\
\text { chain management }\end{array}$ \\
\hline $\begin{array}{l}\text { El-Omari \& Moselhi } \\
(2009)\end{array}$ & $\begin{array}{l}\text { Data acquisition; Work progress monitoring; Resource management; Database } \\
\text { management }\end{array}$ \\
\hline Aouad et al., (2010) & $\begin{array}{l}\text { Establish client requirements; Early contractor involvement; Construction; Operation; } \\
\text { Strategic partnership between client \& contractor; Communicate end-user needs }\end{array}$ \\
\hline Lin \& Su (2013) & $\begin{array}{l}\text { Facility maintenance management; Operations; Ability of maintenance staff to access } \\
\text { information; Support decisions \& improve process throughout project lifecycle; } \\
\text { Identify design conflicts; Procurement }\end{array}$ \\
\hline Zhou et al., (2013) & $\begin{array}{l}\text { Automatic monitoring \& visualization of field operations; Information communication } \\
\text { for construction safety; Real-time location systems for monitoring site activities; } \\
\text { Simulate safety problems of construction processes }\end{array}$ \\
\hline $\begin{array}{l}\text { Heller \& Orthmann } \\
(2014)\end{array}$ & $\begin{array}{l}\text { Life-cycle cost savings; Quality management; Building process efficiency; } \\
\text { Construction Operations; Establish value for involved stakeholders }\end{array}$ \\
\hline $\begin{array}{l}\text { Georgiadou, Hacking, } \\
\text { \& Guthrie (2012) }\end{array}$ & $\begin{array}{l}\text { Pre-design, design, construction, operation, refurbishment, decommissioning, } \\
\text { deconstruction and demolition }\end{array}$ \\
\hline Patacas et al. (2015) & $\begin{array}{l}\text { Facilities management data handover; Design development; Service life planning; } \\
\text { Workforce \& process efficiency }\end{array}$ \\
\hline Wu et al. (2016) & $\begin{array}{l}\text { Automated production process; Design development; Waste management; Life cycle } \\
\text { cost calculations }\end{array}$ \\
\hline Rojas \& Songer (1999) & $\begin{array}{l}\text { Stakeholder engagement; Workflow automation; Teamwork development; Improved } \\
\text { inspection performance; Life-cycle collaborative system }\end{array}$ \\
\hline Kuenzel et al., (2016) & $\begin{array}{l}\text { Project initiation; Real-time automated information exchange; Construction budget \& } \\
\text { schedule; Site management }\end{array}$ \\
\hline
\end{tabular}

\section{RESEARCH METHOD}

As this is a review paper, the research methodology for literature review is adopted from similar survey studies by Chan \& Yi (2014), W. Zhou et al.(2012), Hassan Ibrahim (2013), Ibem \& Laryea (2014), and Guo et al. (2017). The choice of this approach presented the advantage of bringing together evidence from multiple studies on the subject to inform practice. The analysis relates to research of digital technologies from two main perspectives: functions of digital technologies correlating to productivity, and barriers to adoption of digital technologies. A three-stage literature search refined the desktop investigation to present an analysis of relevant journal papers. Digital technology applications have gained traction from practitioners over the last two decades (Ajam, Alshawi, \& Mezher, 2010a); (Heng Li, Chan, Kwok, Wong, \& Skitmore, 2016); (Valero et al., 2015). Hence for the study, authors selected articles published between 1998 and 2018 using Scopus as the main source of literature. Scopus has a wide range of journal index and special features in key word searching and citation analysis compared to other databases like Google Scholar, Science Direct, Web of Science, Taylor \& Francis. The research method consists of three main phases, as shown in figure 1, summarizing the research design and outcome.

Stage 1 - Search by keywords, title, and abstract

A search criterion was designed to select emerging developments on the subject of interest, i.e., application of digital technologies in construction and links to productivity, contained in article keywords, title, and abstract. Articles were searched by rearranging key phrases under 'TITLE-ABS-KEY' menu. Search key words include (but not limited to): 'digital technology AND construction lifecycle; 'digital technology AND productivity AND construction industry'; 'digital technology AND cost AND construction industry'; 'digitization of construction 
projects'; 'industry 4.0 AND construction industry'; 'digital technology AND construction projects'; 'information and communication technology AND construction industry'. This search process initially generated 1880 papers.

Stage 2 - Selection by journal impact and citation prominence

To capture relevant developments, this review is based on carefully selected top ranked, peer reviewed, and English journals only. Sources published under categories of conference, government reports, notes, letters, books, briefing, were excluded at this Stage. As a result, 419 papers were identified from the selected journals for further iteration.

Stage 3 - Selection by visual screening

The papers collected from stage 2 were examined to ensure that the search is focused on the relationship between digital technologies and productivity. This stage is designed to achieve the research objective of finding key functions of digital technologies and linking to productivity. Screening included reading through the abstracts, findings, and conclusions. The criteria for selection was to find a correlation between digital technology applications across the construction life cycle activities and productivity performance. Authors discarded articles that did not focus on the functions of digital technologies and where no links to productivity were found. Finally, the survey qualitatively, aggregated a selected set consisting of 144 papers. These papers focused on the relationship between digital technologies and productivity.

\section{RESULTS}

\subsection{Distribution of publications}

Findings show that Journal of Automation in Construction, Journal of Computing in Civil Engineering, Journal of Construction Engineering and Management, Electronic Journal of Information Technology in Construction, and Canadian Journal of Civil Engineering account for more than $70 \%$ of related publications. Relatively less coverage is observed across the other journals (see figure 2). Contribution is realized from 33 countries, as shown in figure 3. Around $67 \%$ research participation is found from researchers in USA, Canada, and UK. This is perceived logical because industrial and government practices enforce a great emphasis on implementing digital technologies in these countries (Patacas, Dawood, Vukovic, \& Kassem, 2015). An increasing number of publications (see figure 4), indicating growing digital technologies applications in construction industry.

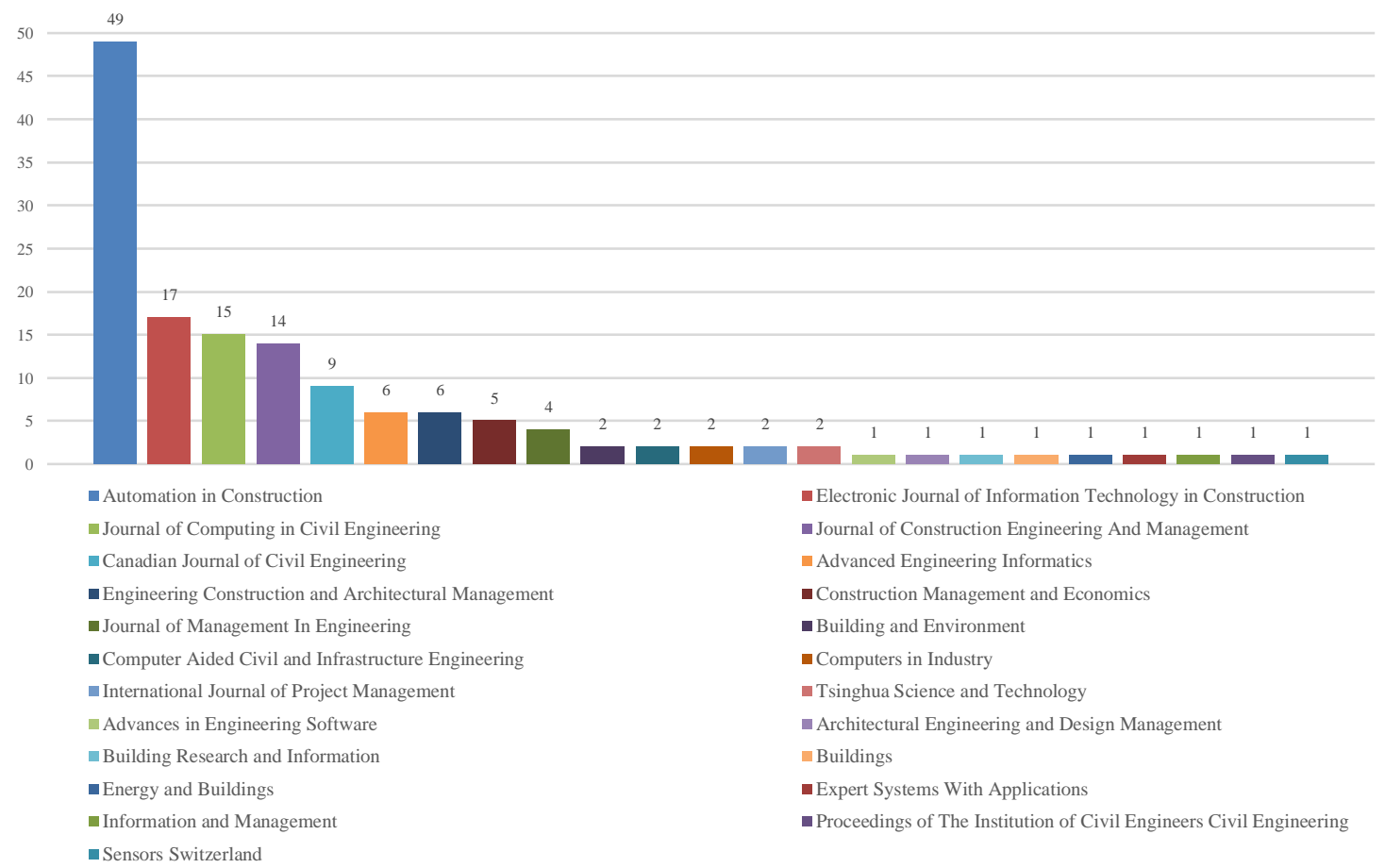


Figure 2: List of selected journals and number of publications

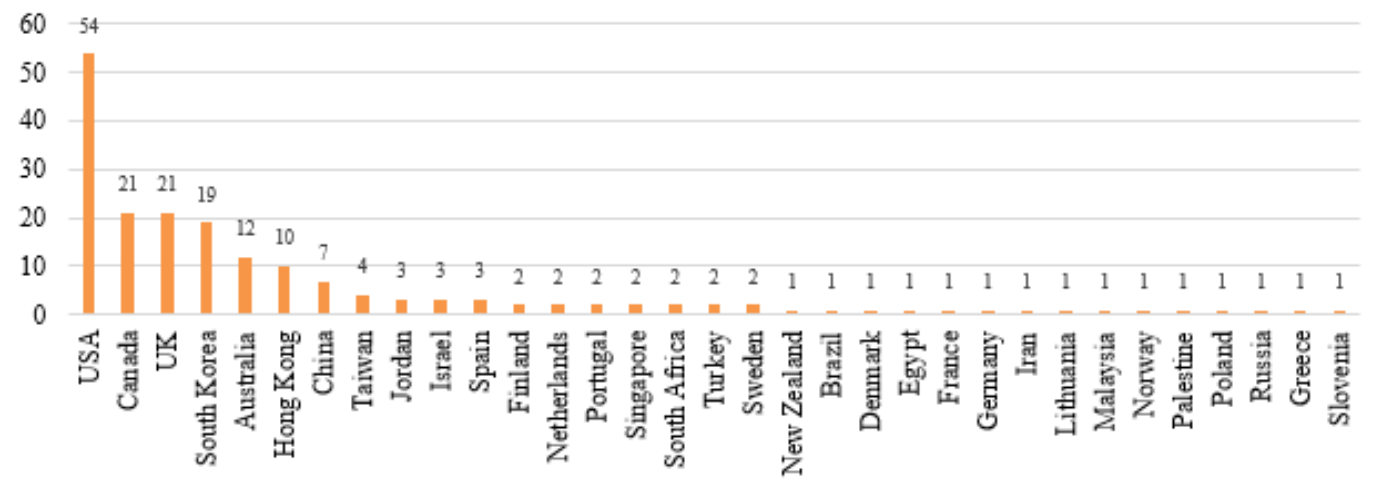

Figure 3: Geographical origin of publications

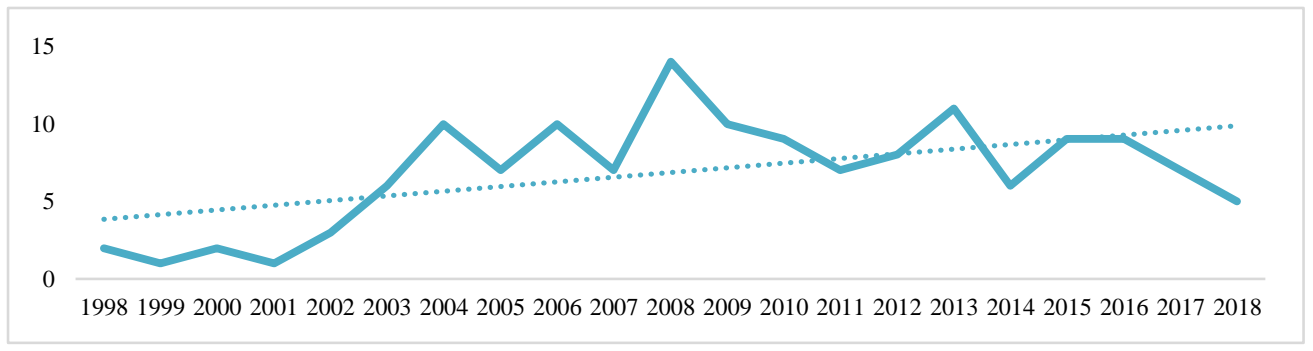

Figure 4: Yearly distribution of publications

Even with the abundance of publications on digital technologies used in construction sector, research on the theoretical roles of digital technologies to directly address productivity is sparse. Thirty two digital technologies were identified, with key functions outlined in Table 4: 3D Printing, Artificial Neural Network (ANN), Artificial Reality (AR), Autonomous vehicle/robotic system, Barcode technology, BIM, Case based reasoning (CBR), Cloud computing, Context aware mobile computing, Electronic commerce (e-commerce) technologies, including webbased project management, WBPM, e-Marketplace, e-payment platforms, and email, Electronic Data Interchange (EDI), Enterprise Resource Planning (ERP), Extensible Markup Language (XML) technology, Internet of Things (IoT), Big data and analytics, Game technology, Geographical Information System (GIS), Global Positioning System (GPS), Infrared, Laser distance and ranging technology (LADAR) / 3D Scanner, Mobile devices (smartphones, tablet, handheld devices, such as the personal digital assistant, PDA), Multimedia technology, Photogrammetry (digital cameras), RFID, Software applications: 3D, 4D, CAD, Ultrasound, Virtual Prototyping, Virtual Reality (VR), Wearable devices, Wireless local area network (WLAN), Wireless Sensor Network (WSN) technologies including Ultra-Wide Band (UWB), Bluetooth, ZigBee, and Wireless technology.

Table 1: Key capabilities of digital technologies sourced from literature

\begin{tabular}{|c|l|l|}
\hline Digital technologies & Key functions linked to productivity & Source \\
\hline $1 . \quad$ 3D Printing & $\begin{array}{l}\text { Additive manufacturing with potential to decrease } \\
\text { manpower requirements and costs, reduce material } \\
\text { wastage, enable on situ repair in areas of limited human } \\
\text { access and resource availability }\end{array}$ & $\begin{array}{l}\text { Camacho et al. } \\
\text { (2018) }\end{array}$ \\
\hline $2 . \quad$ ANN & $\begin{array}{l}\text { Emulate human brain functions to recognise patterns in } \\
\text { processes; most helpful in analysing big volumes of data, } \\
\text { saving time and labour cost }\end{array}$ & $\begin{array}{l}\text { Gong \& Caldas } \\
\text { (2011); Zhang et al. } \\
\text { (2017); Hamelink } \\
\text { (1997) }\end{array}$ \\
\hline
\end{tabular}




\begin{tabular}{|c|c|c|}
\hline Digital technologies & Key functions linked to productivity & Source \\
\hline $\begin{array}{l}\text { 3. Augmented } \\
\text { Reality }\end{array}$ & $\begin{array}{l}\text { Combination of real-world images and virtual images to } \\
\text { provide real time experience to users. Facilitate fieldwork } \\
\text { inspection and defect detection, enhances productivity, } \\
\text { safety, and efficiency }\end{array}$ & $\begin{array}{l}\text { Park, Lee, Kwon, \& } \\
\text { Wang (2013); Abedi, } \\
\text { Fathi, Mirasa, \& } \\
\text { Rawai (2016); Park et } \\
\text { al. (2013) }\end{array}$ \\
\hline $\begin{array}{l}\text { 4. Autonomous } \\
\text { vehicle / robotic } \\
\text { system }\end{array}$ & $\begin{array}{l}\text { Automate and facilitate assembling repetitive or complex } \\
\text { tasks on construction site; increases efficiency, safety, and } \\
\text { reduce labour cost due to minimal human intervention; } \\
\text { enable remote operations; leverage 3D printing } \\
\text { technology }\end{array}$ & $\begin{array}{l}\text { Gambao, Balaguer, \& } \\
\text { Gebhart (2000); } \\
\text { Camacho et al. } \\
\text { (2018) }\end{array}$ \\
\hline $\begin{array}{l}\text { 5. Barcode } \\
\text { technology }\end{array}$ & $\begin{array}{l}\text { Automate acquisition of data, cost and schedule tracking, } \\
\text { and improve speed, reliability, and accuracy of data, can } \\
\text { be integrated with GIS for construction progress } \\
\text { monitoring }\end{array}$ & $\begin{array}{l}\text { Cheng \& Chen } \\
\text { (2002) }\end{array}$ \\
\hline 6. BIM & $\begin{array}{l}\text { Facilitate object oriented physical representation of } \\
\text { building, assist with the visualisation of real-world } \\
\text { objects, coordination among project actors, and } \\
\text { production of construction documents to delivery. BIM- } \\
\text { enabled collaboration saves rework time, cost, and error } \\
\text { throughout the entire life cycle of the building, especially, } \\
\text { pre-planning phase }\end{array}$ & $\begin{array}{l}\text { Turk (2016); Becerik- } \\
\text { Gerber \& Rice } \\
\text { (2010); Irizarry et al. } \\
\text { (2014); Poirier et al. } \\
\text { (2017) }\end{array}$ \\
\hline 7. $\mathrm{CBR}$ & $\begin{array}{l}\text { Uses knowledge retrieved from previous situation to } \\
\text { solve new problems; enhance estimation of construction } \\
\text { cost and duration at pre-planning stage }\end{array}$ & $\begin{array}{l}\text { Yau \& Yang (1998); } \\
\text { Fu \& Fu (2012) }\end{array}$ \\
\hline 8. Cloud computing & $\begin{array}{l}\text { Provide virtual, low cost access to information leveraged } \\
\text { by Internet; effective material management; enables } \\
\text { subscription to required software services without buying } \\
\text { individual hardware; assists managing maintenance cost } \\
\text { and human capital }\end{array}$ & $\begin{array}{l}\text { Ko, Azambuja, \& } \\
\text { Felix Lee (2016); } \\
\text { Parashar (2013) } \\
\text { Pattnayak \& Pradhan } \\
(2016)\end{array}$ \\
\hline $\begin{array}{l}\text { 9. Computer, } \\
\text { software } \\
\text { applications }\end{array}$ & $\begin{array}{l}\text { Storage depot for project information and data processing; } \\
\text { software applications integrated with BIM enable } \\
\text { minimizing total life cycle cost of the project }\end{array}$ & Agdas et al. (2010) \\
\hline $\begin{array}{l}\text { 10. Context aware } \\
\text { mobile computing }\end{array}$ & $\begin{array}{l}\text { Improve construction logistics through wireless access to } \\
\text { context-specific data, information and services. }\end{array}$ & Abedi et al. (2016) \\
\hline $\begin{array}{l}\text { 11. E-commerce } \\
\text { technologies, } \\
\text { WBPM, e- } \\
\text { Marketplace, e- } \\
\text { payment } \\
\text { platforms, and } \\
\text { email }\end{array}$ & $\begin{array}{l}\text { Assist construction project control and monitoring } \\
\text { enabled by internet; facilitate outsourcing, decrease } \\
\text { transaction cost }\end{array}$ & $\begin{array}{l}\text { Cheung et al (2004); } \\
\text { Love \& Irani (2004); } \\
\text { Kong et al. (2004); } \\
\text { Zou \& Seo (2006) }\end{array}$ \\
\hline 12. EDI & $\begin{array}{l}\text { Computer based communication technology that assist } \\
\text { administration of contracts between contractors and } \\
\text { suppliers, facilitate exchange of information between } \\
\text { business parties. Internet based EDI enable more effective } \\
\text { data transmission than traditional EDI; suitable for large } \\
\text { organisations; improve profit margins }\end{array}$ & $\begin{array}{l}\text { Lee et al. (2004); } \\
\text { Finne (2003); Decelle } \\
\text { et al. (2007) }\end{array}$ \\
\hline 13. ERP & $\begin{array}{l}\text { Assist the planning and managing of organisational } \\
\text { resources by integrating business functions to a centrally } \\
\text { controlled computer system; increase firms business value } \\
\text { and productivity }\end{array}$ & Chung et al (2008) \\
\hline
\end{tabular}




\begin{tabular}{|c|c|c|}
\hline Digital technologies & Key functions linked to productivity & Source \\
\hline 14. XML technology & $\begin{array}{l}\text { Automate data interchange leveraged by internet (cost- } \\
\text { effective implementation better than EDI); streamline } \\
\text { business process across various incompatible platforms; } \\
\text { reduced project cost and improved productivity. EDI and } \\
\text { XML improve geographical collaboration, suitable for } \\
\text { small firms }\end{array}$ & $\begin{array}{l}\text { Te (2003); Agdas et } \\
\text { al (2010) }\end{array}$ \\
\hline 15. Game technology & $\begin{array}{l}\text { Facilitate interactive safety training and can be integrated } \\
\text { with BIM; increases worker efficiency, safety, and } \\
\text { operational efficiency }\end{array}$ & Guo et al. (2017) \\
\hline 16. GIS & $\begin{array}{l}\text { Delivers spatial (location related) information that can } \\
\text { eliminate labour intensive data collection, reduce data } \\
\text { entry error and labour cost }\end{array}$ & Irizarry et al. (2013) \\
\hline 17. GPS & $\begin{array}{l}\text { Assist with material management, equipment tracking, } \\
\text { storing and recalling information for logistics purposes; } \\
\text { can be integrated with GIS to reduce construction waste } \\
\text { and improve efficiency }\end{array}$ & $\begin{array}{l}\text { Lee (2009); Young } \\
\text { (2011); Omar \& } \\
\text { Ballal (2009); Li et } \\
\text { al. (2005) }\end{array}$ \\
\hline 18. Infrared & $\begin{array}{l}\text { Enhance communication via real-time data capture and } \\
\text { remote control of multiple devices, for instance mobile } \\
\text { phones }\end{array}$ & $\begin{array}{l}\text { Williams et al. } \\
\text { (2014); Lee et al. } \\
\text { (2009) }\end{array}$ \\
\hline $\begin{array}{l}\text { 19. LADAR)/3D } \\
\text { Scanner }\end{array}$ & $\begin{array}{l}\text { Facilitate data collection and tracking deviation in as built } \\
\text { and as planned design; works in collaboration with } \\
\text { photogrammetry }\end{array}$ & $\begin{array}{l}\text { El-Omari \& Moselhi } \\
(2008)\end{array}$ \\
\hline $\begin{array}{l}\text { 20. Mobile devices } \\
\text { (smart phones, } \\
\text { tablet, handheld } \\
\text { devices, such as } \\
\text { PDA) } \\
\end{array}$ & $\begin{array}{l}\text { Enhance communication and increase transmission of } \\
\text { data, supports WLAN; assist with internet-based } \\
\text { transactions through email or social media network } \\
\text { (enabled by Web } 2.0 \text { technology), improve safety } \\
\text { management }\end{array}$ & $\begin{array}{l}\text { Leung et al. (2008) } \\
\text { Zhang et al. (2017); } \\
\text { Sang et al. (2016); } \\
\text { Ibem \& Laryea } \\
\text { (2014) }\end{array}$ \\
\hline $\begin{array}{l}\text { 21. Multimedia } \\
\text { technology }\end{array}$ & $\begin{array}{l}\text { Assist video recording, progress monitoring of project's } \\
\text { time, cost, quality, and store information in digital format }\end{array}$ & $\begin{array}{l}\text { Akhavian \& } \\
\text { Behzadan (2015) }\end{array}$ \\
\hline $\begin{array}{l}\text { 22. Photogrammetry } \\
\text { (digital cameras) }\end{array}$ & $\begin{array}{l}\text { Capture live on-site pictures used for tracking deviation in } \\
\text { as built and as planned design }\end{array}$ & $\begin{array}{l}\text { Omar et al. (2018); } \\
\text { Ahmed et al. (2012) }\end{array}$ \\
\hline 23. RFID & $\begin{array}{l}\text { Similar in function to Bar Code but enhanced data } \\
\text { acquisition capacity to identify, track, and trace materials } \\
\text { and equipment }\end{array}$ & Sardroud (2012) \\
\hline $\begin{array}{l}\text { 24. Software } \\
\text { applications: 3D, } \\
\text { 4D, CAD }\end{array}$ & $\begin{array}{l}\text { Simulates and optimises flow of information and design } \\
\text { intent among participants }\end{array}$ & $\begin{array}{l}\text { Lei et al. (2015); Lu } \\
\text { \& Lee (2017) }\end{array}$ \\
\hline $\begin{array}{l}\text { 25. Ultrasound } \\
\text { technology }\end{array}$ & $\begin{array}{l}\text { Uses radio frequency like UWB and RFID (but with } \\
\text { limited signal strength) to navigate in dark environment to } \\
\text { track object location, improve positioning performance } \\
\text { when integrated with RFID and GPS }\end{array}$ & $\begin{array}{l}\text { Jang \& Skibniewski } \\
\text { (2009); Valero et al. } \\
\text { (2015); Ahmed et al. } \\
\text { (2012) }\end{array}$ \\
\hline $\begin{array}{l}\text { 26. Virtual } \\
\text { Prototyping }\end{array}$ & $\begin{array}{l}\text { Enable digital mock-up of aspects of construction project } \\
\text { activities, improve construction process management and } \\
\text { reduce cost, leveraged by } 3 \mathrm{D} \text { and } 4 \mathrm{D}\end{array}$ & Li et al. (2008) \\
\hline $\begin{array}{l}\text { 27. Virtual Reality } \\
\text { (VR) }\end{array}$ & $\begin{array}{l}\text { Provide interactive, real-time 3D platform useful in pre- } \\
\text { planning and design stages to collaborate stakeholders for } \\
\text { design review and support customer interface }\end{array}$ & $\begin{array}{l}\text { Carreira et al. (2018); } \\
\text { Whyte (2003) }\end{array}$ \\
\hline 28. Wearable devices & $\begin{array}{l}\text { Enhance visualisation and safety performance, } \\
\text { construction site and hazard management. The devices are } \\
\text { based on technologies ranging from RFID, UWB, GPS, } \\
\text { and Bluetooth }\end{array}$ & $\begin{array}{l}\text { Omar \& Ballal } \\
\text { (2009); Awolusi et al. } \\
\text { (2018) }\end{array}$ \\
\hline
\end{tabular}




\begin{tabular}{|c|c|c|}
\hline Digital technologies & Key functions linked to productivity & Source \\
\hline 29. WLAN & $\begin{array}{l}\text { Capture parameters of projection, such as position, and } \\
\text { assist indoor tracking system, assist information exchange } \\
\text { through an online platform connecting geographically } \\
\text { dispersed stakeholders }\end{array}$ & $\begin{array}{l}\text { Omar \& Ballal } \\
(2009)\end{array}$ \\
\hline $\begin{array}{l}\text { 30. WSN technologies } \\
\text { include UWB, } \\
\text { Bluetooth, Zigbee, } \\
\text { and wireless } \\
\text { technologies }\end{array}$ & $\begin{array}{l}\text { Assist with data acquisition, material management, } \\
\text { location identification, indoor and outdoor, in real-time; } \\
\text { UWB facilitate real time location tracking to overcome } \\
\text { multi path distortion and data accuracy; Zigbee is usually } \\
\text { integrated with RFID for effective data communication } \\
\text { and tag location; collect status information of buildings } \\
\text { during the operation and maintenance phases. Wireless } \\
\text { technologies enable ubiquitous capturing, } \\
\text { communicating, and exchanging information via internet, } \\
\text { enhancing data collection and transfer quickly and } \\
\text { accurately, in real time }\end{array}$ & $\begin{array}{l}\text { Zhang et al. (2017); } \\
\text { Li et al. (2016); Kim } \\
\text { et al. (2011); Heller } \\
\text { \& Orthmann, 2014); } \\
\text { Shin et al. (2011); } \\
\text { Leung et al. (2008); } \\
\text { Cai et al. (2014) }\end{array}$ \\
\hline
\end{tabular}

In summary this section reflected the literature that exists to support a wide range of new transformative technologies and how construction can benefit from these technologies. (Shibeika ahd Harty 2016, Aouad et al. 2016).

\section{DISCUSSION}

With the perspective of construction life cycle activities recognised from literature, this section is an inclusion of key capabilities of digital technologies that improve productivity. Simultaneously these functions are intended to encourage digital technology adoption in the New Zealand construction industry. Findings indicate that a majority of publications focus on applications of digital technologies in design and construction phase to improve the visualization (Patacas et al., 2015), ubiquitous access to on-site and off-site information (Ruwanpura et al., 2012), safety control (Zhou et al., 2012), communication (Vlist et al., 2014), and progress monitoring (Zhang \& Arditi, 2013). Based on the emerging functions of digital technologies, the authors developed three areas for productivity analysis which points towards functions of digital technologies that enable productivity improvement in the construction process; digital access, whole-building whole-of-life decision making and cost engineering reduction.

\subsection{Ubiquitous digital access}

Ubiquitous digital access is the capability afforded by technologies to enable mobile access to information (Shin \& Jang, 2009). The construction industry is highly information dependent. Among the digital access is information about materials, equipment handling, and construction workers activity recognition (Akhavian \& Behzadan, 2016). Good access to data and its management are critical to project management and depends upon shorter construction cycle time and transparent exchange of project information between all parties. Also, transient project locations restrict timely data access. Traditional method of acquiring information is time consuming and error-prone, leading to delays and cost overruns (Tindsley et al., 2008).

Irizarry et al. (2013) addressed the significant applicability of digital technologies, namely BIM, GIS, GPS, UWB, RFID, AR/VR, and LADAR imaging, in real time data acquisition (Irizarry et al., 2013). This enable construction stakeholders working with inadequate access to efficient digital information. This access is beneficial, in particular during design and construction stage, for efficient data handling which in turn improves decision making (Martínez-Rojas et al., 2016), and reduces design deficiencies and clash detection. The latter helps managing the work schedule later in the construction phase (Harty \& Whyte, 2010). Ubiquity of digital access improves communication among the stakeholders who can then identify and minimize design discrepancies (Abeid \& Arditi, 2003). This communication is further enhanced by visual representation of the construction process, using 3D/4D animations leveraged by VR/AR (Ganah et al., 2005). State, behavior, and context of the workers can be achieved by mobile technologies, such as smartphone devices and wearable technology, with embedded sensors (Awolusi et al., 2018). 
The Internet is another ubiquitous source of information that enhances accurate and timely data exchange with real time visibility and remote supervision of the construction process (Husin \& Rafi, 2003). For instance, in the prefabricated public housing projects in Hong Kong, real time information from RFID and GPS is connected with BIM in the developed Internet-of-Things (IOT) enabled platform. This integration enabled stakeholders to gain access to the physical building information, monitor the whole process, and make decisions collaboratively when necessary (Li et al., 2018).

In a survey towards the uptake of mobile computing technology in New Zealand building industry, Liu, Mathrani, \& Mbachu (2017) indicated that adoption of mobile applications provided better client relationship management and satisfaction, which has a positive correlation with sector's overall productivity and profit (Liu, Mbachu, Mathrani, Jones, \& McDonald, 2017). Although the basis of analysis covered a very small survey sample, it provided a starting point for encouraging further uptake of multiple mobile technologies in the sector. Venkatraman \& Yoong (2009) developed a mobile facsimile application, called ClikiFax, to facilitate image-based messaging to a smart phone or fax machine and collaborate time-critical information among contractors, architects, and owners, at remote construction sites. As evident from literature, ubiquitous technologies enable new functionalities from the early design phase to the very end of an asset's life cycle, in real time, irrespective of location (Gerbert et al., 2016).

\subsection{Whole-building whole-of-life (WBWOL) decision making}

The WBWOL framework was commenced by Building Research Association New Zealand (BRANZ) to establish the environmental impacts of building design and encourage more consistent use of building, based on life cycle assessment (LCA). The framework is significant to the New Zealand building industry because it facilitates a stronger connection between supply and demand for construction products. In the academic literature, life cycle considerations focus on benefits of early involvement to overcome technical discrepancies, design deficiencies, and organizational challenges. Life cycle considerations need to start at early design phase to prevent cost and time wastage rather being considered at a later stage (Ibrahim, 2013). In the literature, life cycle considerations focus on benefits of early involvement to overcome technical discrepancies, design deficiencies, and organizational challenges. Evidence of digital technology applications for the entire construction life cycle is sparse but the contribution is discussed and has potential. Digital technologies demonstrate benefit in this regard by offering logistics transparency in the construction process. Digital technologies enable the framework by means of material management, visualization, and real time data management, such as, current production status across building lifecycle (Golparvar-Fard, Bohn, Teizer, Savarese, \& Peña-Mora, 2011). Several studies investigated the use of digital technologies with lifecycle considerations. Quantitative digital tools, such as 3D CAD and BIM are used throughout the lifecycle from design, planning, clash detection, scheduling, estimation, and project management (Ibrahim, 2013). Valero et al. (2015) demonstrates uses of RFID in four main stage of the lifecycle of a facility: planning and design, construction and commission and operation and maintenance. With increasing use of automated data acquisition technologies, such as RFID and GPS, facilitate assessment of as-built phases and integrating LCA-based data into the design process become easier and quicker (Ma et al., 2005). Digital technologies facilitate the management of real-time data, and consequently facilitates improved collaboration and teamwork necessary for lifecycle-based decision making.

Visualization capabilities of BIM enable decision making for operation and maintenance phase activities. This is of interest to project stakeholders to support decision within a whole lifecycle perspective. For instance, in the UK, government mandated BIM adoption in all public projects sustaining from 2016. The initiative is intended to leverage the UK construction strategy of 2025 to reduce whole life cost of built assets by $33 \%$, overall time by $50 \%$ (Chang et al., 2017). In New Zealand a similar government initiative to improve productivity by $20 \%$ by 2020 (Fuemana et al., 2013) could be greatly leverage by digital technologies. The BIM enabled projects driven by BAC New Zealand (2014) showed financial benefits from the integration, in particular workflow efficiency, reduced material and labor waste, and shorter construction time (See table 5). The utilization of BIM across the projects' life cycle point towards a common notion that to get maximum benefit from BIM it is important to use it from inception to completion and that the technologies revolutionize traditional project decision-making by enabling whole-life consideration. Application of advanced information and communication technologies and artificial intelligence supported systems cuts across the entire spectrum of project cycles, improving collaboration, design development, and boosting productivity (Yau \& Yang, 1998; Kumaraswamy et al., 2004; Kuenzel et al., 2016). 
Table 2: BIM case studies in NZ

\begin{tabular}{|c|c|c|}
\hline BIM NZ Case study & $\begin{array}{l}\text { Lifecycle } \\
\text { phase }\end{array}$ & Linking BIM to construction life cycle \\
\hline $\begin{array}{lll}\text { UNITEC's } & \text { integrated } & \text { information } \\
\text { system } & & \end{array}$ & $\begin{array}{l}\text { Operate } \\
\text { Renovate }\end{array}$ & $\begin{array}{l}\text { Asset management } \\
\text { Track space management } \\
\text { Improved workflow efficiency } \\
\text { Instant access to accurate and up-to-date } \\
\text { maintenance schedule } \\
\text { Short response time and greater capacity to attend } \\
\text { maintenance }\end{array}$ \\
\hline $\begin{array}{l}\text { North Shore Hospital's Elective Surgery } \\
\text { Centre by JASMAX }\end{array}$ & $\begin{array}{l}\text { Pre-design } \\
\text { Design } \\
\text { Construction }\end{array}$ & $\begin{array}{l}\text { 3D coordination } \\
\text { Reduced construction time } \\
\text { Enhanced communication with client and project } \\
\text { team members } \\
\text { Greater visibility of MEP and architectural systems } \\
\text { Improved workflow } \\
\text { Early clash detection }\end{array}$ \\
\hline $\begin{array}{l}\text { Kathleen Kilgour Centre procured by } \\
\text { Bay of Plenty DHB }\end{array}$ & $\begin{array}{l}\text { Pre-design } \\
\text { Design } \\
\text { Construction } \\
\text { Operate }\end{array}$ & $\begin{array}{l}\text { Asset management } \\
\text { Digital fabrication } \\
\text { Early clash detection } \\
\text { Digital prototyping and 3D coordination } \\
\text { Enhanced data sharing } \\
\text { Reduced re-work } \\
\text { Enable cloud-based facilities management } \\
\text { YouBIM } \\
\text { Digital access }\end{array}$ \\
\hline $\begin{array}{l}\text { University of Auckland Undergraduate } \\
\text { Laboratories by BECA }\end{array}$ & $\begin{array}{l}\text { Pre-design } \\
\text { Design } \\
\text { Construction } \\
\end{array}$ & $\begin{array}{l}\text { Visualization before and during installation } \\
\text { Reduced material and labor waste } \\
\text { Shorter construction time by two weeks }\end{array}$ \\
\hline $\begin{array}{l}\text { Ara Institute of Canterbury Kahukura } \\
\text { Block by AECOM }\end{array}$ & Design & $\begin{array}{l}\text { Efficient cost estimation } \\
\text { Collaborative design review } \\
\text { Accurate and reliable digital quantity surveying data }\end{array}$ \\
\hline $\begin{array}{l}\text { Christchurch Justice \& Emergency } \\
\text { Services Precinct led by Ministry of } \\
\text { Justice }\end{array}$ & $\begin{array}{l}\text { Design } \\
\text { Construction }\end{array}$ & $\begin{array}{l}\text { Visualization and collaboration } \\
\text { Increased coordination and stakeholder engagement } \\
\text { for better decision making } \\
\text { Early clash detection } \\
\text { Minimize waste } \\
\text { Space management } \\
\text { Risk reduction leading to reduction in contractors' } \\
\text { price }\end{array}$ \\
\hline $\begin{array}{l}\text { Wellington City Council Bracken Road } \\
\text { Flats by Wellington City Council }\end{array}$ & $\begin{array}{l}\text { Design } \\
\text { Operate }\end{array}$ & $\begin{array}{l}\text { Assist better decision making } \\
\text { Capture information cost effectively } \\
\text { Reduced number of site visits } \\
\text { Easy location identification of building elements for } \\
\text { maintenance }\end{array}$ \\
\hline $\begin{array}{l}\text { Ara Institute of Canterbury Kahukura } \\
\text { Block by AECOM }\end{array}$ & Design & $\begin{array}{l}\text { Efficient cost estimation } \\
\text { Collaborative design review } \\
\text { Accurate and reliable digital quantity surveying data }\end{array}$ \\
\hline $\begin{array}{l}\text { University of Auckland Undergraduate } \\
\text { Laboratories by BECA }\end{array}$ & $\begin{array}{l}\text { Pre-design } \\
\text { Design } \\
\text { Construction }\end{array}$ & $\begin{array}{l}\text { Visualization before and during installation } \\
\text { Reduced material and labor waste } \\
\text { Shorter construction time by two weeks }\end{array}$ \\
\hline
\end{tabular}




\subsection{Cost Reduction Engineering}

Another key function of digital technologies is cost reduction engineering (CRE). The CRE concept depends heavily on cost reduction capabilities of digital technologies. When the cost of constructed facilities is reduced, the facilities themselves become more affordable, and, therefore, more accessible to a greater proportion of the population (Slaughter, 1998). Rework and design deviations typically add to life cycle cost overruns. Cost of deviation and rework was discussed by Burati et al., (1992) and Egan (1998) as a high contributor, $12.4 \%$ and 30\% respectively, to total project cost. Harnessing digital technologies can minimize such error and save the cost of rework by optimizing the construction process. Multimedia, VR/AR, and 3D/4D visual imaging technologies help eliminate design error (Dawood \& Mallasi, 2006). A major benefit of visual tools is to identify deviations in asbuilt and as-planned work that account for significant portion of total project cost (Kumaraswamy et al., 2004). In view of this challenge, Omar \& Nehdi (2016) developed a visual system in close range photogrammetry that is able to deliver work progress, continuous monitoring and controlling of construction site activities. The visual monitoring not only reduces unnecessary site visits but also makes it easier to provide corrections, and make timely adjustment to the process, mitigating time and cost consequences.

Another aspect of cost control is by managing safety on site. Construction sites contain several supporting facilities that are required to perform construction activities. These facilities may be exposed to hazards and lead to adverse consequences for the whole construction process, in terms of worker productivity, project completion time, quality and budget. A range of digital technologies, in particular RTLS, PWS, CBR, ANN, and Game Technology, are addressed for enhancing safety education and training, hazard identification and accident prevention (Zhou et al., 2013). The advent of worldwide web and Internet have evolved online business solutions, in particular electronic commerce (e-commerce), to provide cost-effective support for information flow and communication, at any given time (Kong et al., 2004). E-commerce technologies, such as web-based project management, e-Marketplace, electronic payment platforms, and email, facilitate outsourcing work to diverse participants in the construction industry (Love \& Irani, 2004). Cost efficiency is gained through decreased transaction costs, inventory levels, staffing requirements, and procurement cycles. Contractors and owners benefit from this technology by reduced administration and communication costs, and construction costs respectively (Zou \& Seo, 2006). Digital technologies revitalize the construction process by automating activities.

Intelligent systems like BIM, wireless technology and cloud computing (Ibem \& Laryea, 2014), RLTS, geospatial technologies, and vision technologies, such as LADAR (C Kim, Son, Kim, \& Han, 2008) enable data storage, without the need for a physical device, like computer hard drive. This eliminates the need for IT personnel, thus reducing staffing and overhead costs. Automated activities make site intervention less necessary. This can save valuable labor hours and added costs to construction. Wang et al. (2014) succeeded in achieving automated progress control by integrating AR in BIM. The system reduces manual intervention, and time, adding to costeffective deliverable for the entire project. Another emerging automation technology, although long used in the manufacturing sector, is $3 \mathrm{D}$ printing. It is gaining popularity in the construction industry owing to its potential to provide flexibility in design, reduced manpower, construction time, and waste (Wu et al., 2016). 3D printing allows inclusion of BIM in the construction process to further improve scheduling requirements of the project, reducing construction time on site, production cost, and overall lifecycle cost. Given the scale of Auckland housing shortage and rebuild of Christchurch, automation technologies may leverage meeting demands in the country (Buckett, 2013).

Moreover, existing evidence (Gambatese and Hallowell, 2011) revealed that decreased cost, competitive advantage, higher quality and increased productivity are the most highly rated expected benefits of technology innovation. Results from literature show that economic conditions (Ozorhon et al., 2010), high construction cost (Suprun and Stewart, 2015), and initial/project costs rather than life cycle costs (Hemstrom et al., 2017) are the top barriers. Whereas, researchers from Malaysia (Ramilo and Embi, 2014) identified the following barriers to the adoption of innovative technologies which would seem to relate with the experience of NZ innovators and construction companies: financial; technological; process; organizational; psychological; and governmental barriers that prevent the adoption of mature and cost-effective technologies. Financial concerns act as a prominent barrier to technology uptake. Companies tend to innovate to increase their profitability, but they cannot innovate unless their economic condition allows. 


\section{CHALLENGES OF DIGITAL TECHNOLOGY IMPLEMENTATION FOR CONSTRUCTION LIFE CYCLE ACTIVITIES}

From the above literature, it may be inferred that the implementation of digital technology in construction projects enables an increase in collaboration, integration, monitoring, safety, cross reference of knowledge, delineated coordination practices among project participants. Based on findings, these functions could significantly contribute to productivity improvements in the construction projects. Although Vlist et al.(2014) advocated that a minimum level of ICT requirement can benefit production cost advantage, and a number of technical, financial, and organizational barriers come in the way DT adoption, as illustrated by Zou \& Seo (2006) and Ibrahim (2013). Despite making progress in its development, digital technology adoption meets with skepticism because of fragmented nature of the industry (Hartmann, Van Meerveld, Vossebeld, \& Adriaanse, 2012); security and confidentiality concerns (Strachan \& Stephenson, 2009; Changyoon Kim et al., 2013); lack of supporting data and knowledge of benefits (Palaneeswaran \& Kumaraswamy, 2003); incompatibility or interoperability issues between applications/technologies (Duzgun Agdas et al., 2010; Changyoon Kim et al., 2013; Patacas et al., 2015); increased time/effort in creating 3D models (Khatib, Chileshe, \& Sloan, 2007; Q. Lu \& Lee, 2017); resource requirements, and coordination problems (Harty \& Whyte, 2010; Wu et al., 2016); costing and management issues (Sacks, 2004; Eadie, Perera, Heaney, \& Carlisle, 2007; Hewage, Ruwanpura, \& Jergeas, 2008; Merschbrock \& Munkvold, 2015). These findings reflect a similarity to the technology barrier factors observed in New Zealand construction industry, including affordability, lack of data management, risk aversion, and lack of creative vision (Wilkinson et al., 2017).

\section{CONCLUSION}

From a review of 144 papers, 32 digital technologies were identified, and three emerging functions of digital technologies analyzed for their contribution to productivity improvements. BIM, RFID, Cloud Computing, GIS, GPS, and Mobile Computing appear to be the emerging productivity enhancing technologies. The array of international studies concluded that digital technologies demonstrate great potential to productivity gains and profit margins. This is a significant resource to encourage digitization in the New Zealand building industry. Three of the emerging functions are highlighted to assist construction practitioners to invest into digital technologies and develop adoption strategies in future or improve the uptake of technologies in NZ building industry for improving sector productivity.

Previous evidence revealed that financial, technological, process, organizational, psychological and governmental barriers would prevent the adoption of mature and cost-effective technologies in New Zealand. Financial concerns can act as a prominent barrier to technology uptake. In the context of New Zealand, several technologies, namely BIM, RLTS, 3D printing, and mobile technologies, have promising potential to enhance workflow efficiency and some studies are already exploring the opportunity. Future efforts should be made to examine the processes required for incorporating new digital technologies, industry wide. This will leverage achievement of the national agenda of $20 \%$ productivity improvement by 2020 .

\section{REFERENCES}

Abeid, J., \& Arditi, D. (2003). Photo-net: An integrated system for controlling construction progress. Engineering, $\begin{array}{llll}\text { Construction and Architectural } & \text { Management, 10(3), }\end{array}$ http://doi.org/10.1108/09699980310478412

Akhavian, R., \& Behzadan, A. H. (2016). Smartphone-based construction workers' activity recognition and classification. Automation in Construction, 71(Part 2), 198-209. http://doi.org/10.1016/j.autcon.2016.08.015

Aouad, G., Ozorhon, B., \& Abbott, C. (2010). Facilitating innovation in construction. Construction Innovation, 10(4), 374-394. http://doi.org/10.1108/14714171011083551

Awolusi, I., Marks, E., \& Hallowell, M. (2018). Wearable technology for personalized construction safety monitoring and trending: Review of applicable devices. Automation in Construction, 85(July 2016), 96106. http://doi.org/10.1016/j.autcon.2017.10.010

Balfour Beatty. (2017). A Digital Future for the Infrastructure Industry, (June), 13.

BIM Acceleration Committee. (2014). New Zealand Building Information Modelling (BIM) Handbook A guide to enabling BIM on building projects. 
BIMinNZ. Wellington City Council Bracken Road Flats (2014). Retrieved from https://www.biminnz.co.nz/casestudies/

BRANZ. (2014). Building a better New Zealand Annual Review 2014. Retrieved from http://www.buildingabetternewzealand.co.nz/

Brandon, P.S. and Lu, S.L. (2008), Clients Driving Innovation, Wiley-Blackwell, West Sussex, Chichester.

Buckett, N. (2013). Building Better for Less - Advanced Residential Construction Techniques.

Buehler, M., \& Gerbert, P. (2017). How Elon Musk and other pioneers are shaking up the construction industry. Retrieved from https://www.weforum.org/agenda/2017/03/elon-musk-innovation-construction-industry

Burati, J. L., Farrington, J. J., \& Ledbetter, W. B. (1992). Causes of Quality Deviations in Design and Construction. Journal of Construction Engineering and Management, 118(1), 34-49. http://doi.org/10.1061/(ASCE)0733-9364(1992)118:1(34)

Business Growth Agenda. (2017). Building a Digital Nation Part of BGA Building Innovation. Retrieved from http://www.mbie.govt.nz/info-services/science-innovation/digital-economy/building-a-digital-nation.pdf

Cai, H., Andoh, A. R., Su, X., \& Li, S. (2014). A boundary condition based algorithm for locating construction site objects using RFID and GPS. Advanced Engineering Informatics, 28(4), 455-468. http://doi.org/10.1016/j.aei.2014.07.002

Carson, C., \& Abbott, M. (2012). A review of productivity analysis of the New Zealand construction industry. Australasian Journal of Construction Economics and Building, 12(3), 1-15. http://doi.org/10.5130/ajceb.v12i3.2584

Chang, C.-Y., Pan, W., \& Howard, R. (2017). Impact of Building Information Modeling Implementation on the Acceptance of Integrated Delivery Systems: Structural Equation Modeling Analysis. Journal of Construction Engineering and Management, 143(8). http://doi.org/10.1061/(ASCE)CO.19437862.0001335

Civil Engineering Research Foundation [CERF] (1996), 'Needed: Lower Risks, More R\&D, Architectural Record, 13 January.

Cory, C. and Bozell, D. (2001), '3D Modelling for the architectural engineering and construction industry, International Conference Graphicon, Nizhny Novgorod, Russia, http://www.graphicon.ru/

Dawood, N., \& Mallasi, Z. (2006). Construction workspace planning: Assignment and analysis utilizing 4D visualization technologies. Computer-Aided Civil and Infrastructure Engineering, 21(7), 498-513. http://doi.org/10.1111/j.1467-8667.2006.00454.x

EBOSS. (2017). BIM in New Zealand - an industry-wide view Baseline information on the use of BIM across the New Zealand construction industry. EBOSS. Retrieved from http://www.eboss.co.nz/bim-in-nz-anindustry-wide-view

Egan, J. (1998). Rethinking construction. Structural Engineer.

El-Omari, S., \& Moselhi, O. (2009). Data acquisition from construction sites for tracking purposes. Engineering, Construction and Architectural Management, 16(5), 490-503. http://doi.org/10.1108/09699980910988384

Froese, T. M. (2010). The impact of emerging information technology on project management for construction. Automation in Construction, 19(5), 531-538. http://doi.org/10.1016/j.autcon.2009.11.004

Fuemana, J., Puolitaival, T., \& Davies, K. (2013). Last Planner System - a step towards improving the productivity of New Zealand construction. Proceedings for the 21th Annual Conference of the International Group for Lean Construction, 679-688.

Gambatese, J.A. and Hallowell, M. (2011), 'Factors that influence the development and diffusion of technical innovations in the construction industry', Construction Management and Economics, 29(5), 507-517.

Ganah, A. A., Bouchlaghem, N. B., \& Anumba, C. J. (2005). Viscon: Computer visualisation support for constructability. Electronic Journal of Information Technology in Construction, 10. Retrieved from https://www.scopus.com/inward/record.uri?eid=2-s2.0-

21344441909\&partnerID=40\&md5=e2ead583ad28844e2367b6bbce1858ba

Gledson, J. and Phoenix, C. (2017), 'Exploring organisational attributes affecting the innovativeness of UK SMEs', Construction Innovation, 17(2), 224-243.

Guo, B. H. W., Scheepbouwer, E., Yiu, T. W., \& González, V. A. (2017). Overview and Analysis of Digital Technologies for Construction Safety Management. In 41st AUBEA (pp. 1-10). Melbourne: AUBEA. Retrieved from https://ir.canterbury.ac.nz/bitstream/handle/10092/14583/OVERVIEW AND ANALYSIS 


\section{OF DIGITAL TECHNOLOGIES DESIGNED FOR CONSTRUCTION SAFETY}

MANAGEMENT.pdf? sequence $=2 \&$ isAllowed $=\mathrm{y}$

Hamelink, C. J. (1997). New Information and Communication Technologies, Social Development and Cultural Change. Development, 48(86), 1-37. http://doi.org/10.1177/135050849854011

Harty, C., \& Whyte, J. (2010). Emerging hybrid practices in construction design work: Role of mixed media. Journal of Construction Engineering and Management, 136(4), 468-476. http://doi.org/10.1061/(ASCE)CO.1943-7862.0000146

Heller, A., \& Orthmann, C. (2014). Wireless technologies for the construction sector - Requirements, energy and cost efficiencies. Energy and Buildings, 73, 212-216. http://doi.org/10.1016/j.enbuild.2013.12.019

Hemstrom, K., Mahapatra, K. and Gustavsson, L. (2017), 'Architects' perception of the innovativeness of the Swedish construction industry', Construction Innovation, 17(2), 244-260.

Husin, R., \& Rafi, A. (2003). The impact of Internet-enabled computer-aided design in the construction industry. Automation in Construction, 12 (5 SPEC.), 509-513. http://doi.org/10.1016/S0926-5805(03)00037-2

Ibem, E. O., \& Laryea, S. (2014). Survey of digital technologies in procurement of construction projects. Automation in Construction, 46, 11-21. http://doi.org/10.1016/j.autcon.2014.07.003

Ibrahim, N. H. (2013). Reviewing the evidence: use of digital collaboration technologies in major building and infrastructure projects. Journal of Information Technology in Construction, 18, 40-63. Retrieved from https://www.scopus.com/inward/record.uri?eid=2-s2.084876909628\&partnerID=40\&md5=c8bb177074736c1481d04a91f566f269

ICCPM. (2014). Submission for the Australian Government's Productivity Commission Public Inquiry Into Public Infrastructure. Retrieved from http://www.pc.gov.au/_data/assets/pdf_file/0019/134272/sub105infrastructure.pdf

ICT.govt.nz. (2017). Digital 5 (D5). Retrieved from https://www.ict.govt.nz/governanceandleadership/international-leadership/d5-wellington-2018/

Irizarry, J., Karan, E. P., \& Jalaei, F. (2013). Integrating BIM and GIS to improve the visual monitoring of construction supply chain management. Automation in Construction, 31, 241-254. http://doi.org/10.1016/j.autcon.2012.12.005

Jones, M. and Saad, M. (2003), Managing innovation in construction, Thomas Telford, London, UK.

Kim, C., Park, T., Lim, H., \& Kim, H. (2013). On-site construction management using mobile computing technology. Automation in Construction, 35, 415-423. http://doi.org/10.1016/j.autcon.2013.05.027

Kim, C., Son, H., Kim, H., \& Han, S. H. (2008). Applicability of flash laser distance and ranging to threedimensional spatial information acquisition and modeling on a construction site. Canadian Journal of Civil Engineering, 35(11), 1331-1341. http://doi.org/10.1139/L08-082

Kong, S. C. W., Li, H., Hung, T. P. L., Shi, J. W. Z., Castro-Lacouture, D., \& Skibniewski, M. (2004). Enabling information sharing between E-commerce systems for construction material procurement. Automation in Construction, 13(2), 261-276. http://doi.org/10.1016/j.autcon.2003.08.011

Kuenzel, R., Teizer, J., Mueller, M., \& Blickle, A. (2016). SmartSite: Intelligent and autonomous environments, machinery, and processes to realize smart road construction projects. Automation in Construction, 71, 21 33. http://doi.org/10.1016/j.autcon.2016.03.012

Kumaraswamy, M. M., Ng, S. T., Ugwu, O. O., Palaneeswaran, E., \& Rahman, M. M. (2004). Empowering collaborative decisions in complex construction project scenarios. Engineering, Construction and Architectural Management, 11(2), 133-142. http://doi.org/10.1108/09699980410527876

Latham, M. (1994). Constucting the team: joint review of procurement and contractual arrangements in the United Kingdom construction industry. Hmso, 53(9), 1689-1699. http://doi.org/10.1017/CBO9781107415324.004

Lee, J. H., Song, J. H., Oh, K. S., \& Gu, N. (2013). Information lifecycle management with RFID for material control on construction sites. Advanced Engineering Informatics, 27(1), 108-119. http://doi.org/10.1016/j.aei.2012.11.004

Li, C. Z., Xue, F., Li, X., Hong, J., \& Shen, G. Q. (2018). An Internet of Things-enabled BIM platform for on-site assembly services in prefabricated construction. Automation in Construction, 89(January), 146-161. http://doi.org/10.1016/j.autcon.2018.01.001

Li, H., Chen, Z., Yong, L., \& Kong, S. C. W. (2005). Application of integrated GPS and GIS technology for reducing construction waste and improving construction efficiency. Automation in Construction, 14(3), 323-331. http://doi.org/10.1016/j.autcon.2004.08.007 
Lin, Y.-C., \& Su, Y.-C. (2013). Developing mobile- and BIM-based integrated visual facility maintenance management system. The Scientific World Journal, 2013. http://doi.org/10.1155/2013/124249

Liu, T., Mathrani, A., \& Mbachu, J. (2017). Hunting the Popular Construction Apps. Proceedings - Asia-Pacific World Congress on Computer Science and Engineering 2016 and Asia-Pacific World Congress on Engineering 2016, APWC on CSE/APWCE 2016, 205-211. http://doi.org/10.1109/APWC-onCSE.2016.042

Liu, T., Mbachu, J., Mathrani, A., Jones, B., \& McDonald, B. (2017). The Perceived Benefits of Apps by Construction Professionals in New Zealand. Buildings, 7(4), 111. http://doi.org/10.3390/buildings7040111

Loosemore, M. (2014), Innovation, Strategy and Risk in Construction, Routledge, Oxon.

Love, P. E. D., \& Irani, Z. (2004). An exploratory study of information technology evaluation and benefits management practices of SMEs in the construction industry. Information and Management, 42(1), 227242. http://doi.org/10.1016/j.im.2003.12.011

Ma, Z., Shen, Q., \& Zhang, J. (2005). Application of 4D for dynamic site layout and management of construction projects. Automation in Construction, 14(3), 369-381. http://doi.org/10.1016/j.autcon.2004.08.011

Macgregor, C. (2017). Why aren 't more homes better ?, (May), 59-60.

Martínez-Rojas, M., Marín, N., \& Vila, M. A. (2016). The role of information technologies to address data handling in construction project management. Journal of Computing in Civil Engineering, 30(4). http://doi.org/10.1061/(ASCE)CP.1943-5487.0000538

MBIE (2016), Building Better Homes, Towns and Cities. Retrieved from http://www.mbie.govt.nz/infoservices/science-innovation/national-science-challenges/buildingbetter-homes

Miettinen, R., \& Paavola, S. (2014). Beyond the BIM utopia: Approaches to the development and implementation of building information modeling. Automation in Construction, 43, 84-91. http://doi.org/10.1016/j.autcon.2014.03.009

New Zealand Productivity Commission. (2012). Housing affordability inquiry. Wellington: The New Zealand Productivity Commission.

NZIER (2014), Bespoke residential housing demand and construction innovation, Retrieved from https://nzier.org.nz/static/media/filer_public/75/d9/75d98949-d425-4dcb-b9a919404be4bce2/11024_bespoke_residential_housing.pdf

Noktehdan, M., Shahbazpour, M. and Wilkinson, S. (2015), Driving innovative thinking in the New Zealand construction industry, Buildings, https://doi.org/10.3390/buildings5020297

O'Sullivan, D. (2002), 'Framework for managing development in the networked organization', Journal of computers in industry (Elsevier Science Publishers B.V.), 47(1): 77-88.

Omar, T., \& Nehdi, M. L. (2016). Data acquisition technologies for construction progress tracking. Automation in Construction, 70, 143-155. http://doi.org/10.1016/j.autcon.2016.06.016

Ozorhon, B., Abbott, C., Aouad, G. and Powell, J. (2010), Innovation in construction: a project life cycle approach, SCRI Research Report, Salford, 1-49.

Patacas, J., Dawood, N., Vukovic, V., \& Kassem, M. (2015). BIM for facilities management: Evaluating BIM standards in asset register creation and service life planning. Journal of Information Technology in Construction, 20, 313-331. Retrieved from https://www.scopus.com/inward/record.uri?eid=2-s2.084979562033\&partnerID $=40 \& \mathrm{md} 5=02 \mathrm{~d} 973 \mathrm{ebc58cc} 93654 \mathrm{dca} 8857 \mathrm{ad} 21627$

PWC. (2016). Valuing the role of construction in the New Zealand economy.

Ramilo, R. and Embi, M.R.B. (2014), 'Critical analysis of key determinants and barriers to digital innovation adoption among architectural organizations', Science Direct, 3, 431-451.

FSSS (Russian Federal State Statistics Service) (2014), available at: www.gks.ru/ (accessed 21 April 2014).

Ruwanpura, J. Y., Hewage, K. N., \& Silva, L. P. (2012). Evolution of the i-Booth $\bigodot$ onsite information management kiosk. Automation in Construction, 21(1), 52-63. http://doi.org/10.1016/j.autcon.2011.05.012

Schoenborn, J. (2012), 'A case study approach to identifying the constraints and barriers to design innovation for modular construction' Unpublished MS Thesis, Virginia Polytechnic Institute and State University, Blacksburg, VA.

Sepasgozar, S.M.E., Loosemore, M. and Davis, S.R. (2016), 'Conceptualising information and equipment technology adoption in construction: a critical review of existing research', Engineering, Construction and Architectural Management, 23(2), 158-176. 
Shelton, J., Martek, I. and Chen, C. (2016), 'Implementation of innovative technologies in small-scale construction firms: five Australian case studies’, Engineering, Construction and Architectural Management, 23(2), 177 191.

Shibeika, A. and Harty, C. (2015), 'Diffusion of digital innovation in construction: a case study of a UK engineering firm', Construction Management and Economics, 33, 453-466.

Shin, D. H., \& Jang, W. S. (2009). Utilization of ubiquitous computing for construction AR technology. Automation in Construction, 18(8), 1063-1069. http://doi.org/10.1016/j.autcon.2009.06.001

Skibniewski, M.J. (2014), 'Information technology applications in construction safety assurance', Journal of Civil Engineering and Management, 20(6), 778-794.

Statistics NZ (2012), Research and development survey, Available at http://www.stats.govt.nz/browse_for_stats/businesses/research_and_development/ResearchandDevelop me ntSurvey_HOTP2012.aspx

Stewart, R. A., Mohamed, S. and Marosszeky, M. (2004), 'An empirical investigation into the link between information technology implementation barriers and coping strategies in the Australian construction industry', Construction Innovation: Information, Process, Management, 4(3), 155-171.

Suprun, E.V. and Stewart, R.A. (2015), 'Construction innovation diffusion in the Russian Federation: Barriers, drivers and coping strategies', Construction Innovation, 15(3), 278-312.

Venkatraman, S., \& Yoong, P. (2009). Role of mobile technology in the construction industry - A case study. International Journal of Business Information Systems, 4(2), 195-209. http://doi.org/10.1504/IJBIS.2009.022823

Wang, X., Truijens, M., Hou, L., Wang, Y., \& Zhou, Y. (2014). Integrating Augmented Reality with Building Information Modeling: Onsite construction process controlling for liquefied natural gas industry. Automation in Construction, 40, 96-105. http://doi.org/10.1016/j.autcon.2013.12.003

World Economic Forum (2016), Shaping the future of construction: a breakthrough in mindset and technology, World Economic Forum, UK, 1-64

Whyte, J., \& Lobo, S. (2010). Coordination and control in project-based work: Digital objects and infrastructures for delivery. Construction Management and Economics, 28(6), 557-567. http://doi.org/10.1080/01446193.2010.486838

Wu, P., Wang, J., \& Wang, X. (2016). A critical review of the use of 3-D printing in the construction industry. Automation in Construction, 68, 21-31. http://doi.org/10.1016/j.autcon.2016.04.005

Xue, X., Zhang, R., Yang, R.J. and Dai, J. (2014), 'Innovation in construction: a critical review and future research', International Journal of Innovation Science, 6(2), 111-126.

Zhang, C., \& Arditi, D. (2013). Automated progress control using laser scanning technology. Automation in Construction, 36, 108-116. http://doi.org/10.1016/j.autcon.2013.08.012

Zhou, W., Whyte, J., \& Sacks, R. (2012). Construction safety and digital design: A review. Automation in Construction, 22, 102-111. http://doi.org/10.1016/j.autcon.2011.07.005

Zhou, Z., Irizarry, J., \& Li, Q. (2013). Applying advanced technology to improve safety management in the construction industry: a literature review. Construction Management and Economics, 31(6), 606-622. http://doi.org/10.1080/01446193.2013.798423

Zou, P. X. W., \& Seo, Y. (2006). Effective applications of e-commerce technologies in construction supply chain: Current practice and future improvement. Electronic Journal of Information Technology in Construction, 11, 127-147. Retrieved from https://www.scopus.com/inward/record.uri?eid=2-s2.033645753220\&partnerID=40\&md5=3e226d490e453a3f8db8fb783772b4dd 